\title{
EFFECT OF PHENYLBUTAZONE (3,5 DIOXO-1,2-DIPHENYL-4-N- BUTYLPYRAZOLIDINE) ON RENAL CLEARANCE OF URATE AND OTHER DISCRETE RENAL FUNCTIONS IN GOUTY SUBJECTS ${ }^{1}$
}

\author{
By TSAI FAN YU, JONAS H. SIROTA,² AND ALEXANDER B. GUTMAN \\ (From the Department of Medicine, The Mount Sinai Hospital, and the Department of Medicine, \\ Columbia University College of Physicians and Surgeons, New York, N. Y.)
}

(Submitted for publication June 22, 1953; accepted July 23, 1953)

Phenylbutazone is a potent analgesic agent currently employed in the treatment of various arthritic disorders (1) including acute gouty arthritis $(1,2)$. It is generally agreed that administration of the drug to gouty subjects effects a sharp lowering of the serum urate level $(1,2)$. The mechanism by which this is accomplished is still obscure.

Evidence that phenylbutazone is a uricosuric drug which depresses tubular reabsorption of urate has been presented elsewhere $(2,3)$. Further data are recorded here. These deal in greater detail with a) the acute and protracted effects of intravenous and oral phenylbutazone administration upon the renal clearance of urate and upon serum urate concentration; b) the effects of intravenously administered phenylbutazone upon the renal clearances of inulin, endogenous creatinine and $\mathrm{PAH}$, the urinary excretion of sodium, potassium, chloride and inorganic phosphate, and upon $\mathrm{Tm}_{\mathbf{P A H}}$; and c) the effects of simultaneous administration of phenylbutazone and probenecid (Benemid) upon urinary urate excretion.

\section{METHODS}

The acute effects of intravenously administered phenylbutazone on the simultaneous renal clearances of urate, inulin, endogenous creatinine and p-aminohippurate, using techniques previously described (4), were studied in ten gouty subjects in the intercritical phase of the disease. All abstained from meat and purine-rich food for three days prior to the study, which was started in the morning during the post-absorptive state. Liberal quantities of water were administered orally to maintain urine flows higher than $3 \mathrm{cc}$. per min. throughout the course of the acute clearance determinations. Following three 10 to 15 minute control urine collection periods, 1 or $2 \mathrm{Gm}$. of

1 Supported in part by grants from the National Institute of Arthritis and Metabolic Diseases, National Institutes of Health, U. S. Public Health Service; and the American Heart Association.

2 Rosenstock Fellow in Medicine. phenylbutazone ( 12 to $27 \mathrm{mg}$. per $\mathrm{Kg}$. body weight) as the sodium salt in 20 per cent solution, further diluted in $100 \mathrm{cc}$. of normal saline solution, were administered intravenously at a rate of approximately $5 \mathrm{cc}$. per min. After the drug had been infused the bladder was washed with distilled water and urine was collected for six to eight 15 to 20 minute periods. Urine collections were continued every two hours during the day and every four hours during the night for an additional 18 to 20 hours in order to follow endogenous creatinine and urate clearances.

In two of the subjects, simultaneous inulin, p-aminohippurate and urate clearances were determined during slow phenylbutazone infusions so as to correlate the effects with rising plasma phenylbutazone concentrations. In three additional subjects this correlation was studied following rapid infusion of the drug. In two of the subjects the effect of phenylbutazone upon $\mathrm{Tm}_{\mathrm{PAB}}$ was studied using standard techniques (5).

The effects of intravenous administration of phenylbutazone on the renal excretion of sodium, potassium, chloride, inorganic phosphate and urate, and on the endogenous creatinine clearance, were studied in three hospitalized gouty subjects during a three-day control period, for two to four days of phenylbutazone administration, and three days thereafter. These subjects were maintained on a constant weighed diet and constant salt and water intake. The daily caloric intake was 1800 for two of the subjects and 1600 for the third. The protein intake was $60 \mathrm{Gm}$. per day for all, and the sodium chloride intake 3.5 $\mathrm{Gm}$. per day for two, and $2.5 \mathrm{Gm}$. per day for one. Urine was obtained by spontaneous voiding, the collection periods being 9 a.m. to 3 p.m., 3 p.m. to 9 p.m. and 9 p.m. to 9 a.m. After three control period days $0.8 \mathrm{Gm}$. of phenylbutazone was administered intravenously in 0.2 per cent solution made up in $\mathbf{5}$ per cent glucose; this was delivered in divided doses of $0.2 \mathrm{Gm}$. each at 9 a.m. and 3 p.m. and $0.4 \mathrm{Gm}$. at 9 p.m. Blood samples were obtained just prior to each infusion.

The effect of orally administered phenylbutazone on the daily urinary output of urate was also studied in eight ambulatory subjects pursuing their normal daily activities. They received a 60 to $70 \mathrm{Gm}$. protein diet for 3 to 10 days preceding the control urine collections. After three 24hour control urines and one or two control plasma urate determinations were obtained, $0.8 \mathrm{Gm}$. of phenylbutazone was administered daily in four divided doses for four to 
seven days. Plasma urate concentrations were determined periodically and urinary urate excretion measured daily throughout the period of study. In one of the subjects, T-1824 spaces were measured before and after 24,48 and 96 hours of drug administration.

The effect of simultaneous administration of phenylbutazone and probenecid upon urinary urate excretion was studied in seven subjects.

The analytical methods for inulin, PAH, creatinine, sodium, potassium, chloride, inorganic phosphate and urate determinations in plasma and urine were those previously employed in the corresponding probenecid study (4). All blood samples were heparinized and the analyses were performed on plasma. In order to ascertain whether phenylbutazone interfered with the method employed for urate determination in plasma and urine, the following studies were performed: 1) Serial dilutions of phenylbutazone (10 to $40 \mathrm{mg}$. per cc.) were added to standard urate solutions and to urine; 2) varying proportions of urine from a subject taking phenylbutazone were added to standard urate solutions and to urine from a subject not taking phenylbutazone; 3 ) equal portions of plasma from a subject receiving phenylbutazone were mixed with plasma from a subject not receiving the drug;4) all of the mixtures represented in 1,2 , and 3 were subjected to uricase digestion. In none of these studies was there evidence of interference with the recoveries of urate.

Plasma phenylbutazone concentrations were determined

TABLE I

Acute effects of intravenous administration of phenylbutazone $(P B)$ on renal clearances of urate, inulin and $P A H$ in ten subjects with non-tophaceous gout

(Patients listed in descending order of drug dosage $/ \mathrm{Kg}$. body weight)

\begin{tabular}{|c|c|c|c|c|c|c|c|}
\hline \multirow[b]{2}{*}{$\begin{array}{l}\text { Subject } \\
\text { (Age) }\end{array}$} & \multirow[b]{2}{*}{ Period } & \multirow[b]{2}{*}{ Purate } & \multicolumn{3}{|c|}{ Renal clearances } & \multicolumn{2}{|c|}{ Clearance ratios } \\
\hline & & & Curste & $\mathrm{C}_{\text {In }}$ & $\mathrm{C}_{\mathrm{PAH}}$ & $\begin{array}{l}\mathrm{C}_{\text {urate }} / \mathrm{C}_{\text {In }} \\
\times 100\end{array}$ & $\mathrm{C}_{I_{\mathrm{D}} / \mathrm{C}_{\mathrm{PAH}}}$ \\
\hline \multirow{2}{*}{$\begin{array}{l}\text { L. W. } \\
44\end{array}$} & $\begin{array}{c}\text { min. } \\
\text { Control }\end{array}$ & $\begin{array}{c}m g . \% \\
8.3 \\
(27 \mathrm{mg} / \mathrm{Kg})\end{array}$ & $\begin{array}{l}c c . / m i n . \\
4.22\end{array}$ & $\begin{array}{l}c c . / \min . \\
105\end{array}$ & $\begin{array}{l}c c . / \min . \\
449\end{array}$ & 4.03 & 0.234 \\
\hline & $\begin{array}{r}15 \\
30 \\
45 \\
60 \\
75 \\
105 \\
135\end{array}$ & $\begin{array}{l}8.1 \\
7.6 \\
7.4 \\
7.2 \\
7.2 \\
7.2 \\
7.2\end{array}$ & $\begin{array}{l}16.3 \\
37.6^{*} \\
19.7 \\
17.3 \\
16.7 \\
14.1 \\
13.1\end{array}$ & $\begin{array}{l}97.4 \\
104 \\
102 \\
107 \\
106 \\
105 \\
110\end{array}$ & $\begin{array}{l}457 \\
364 \\
401 \\
395 \\
392 \\
395 \\
407\end{array}$ & $\begin{array}{l}16.7 \\
36.2 \\
19.3 \\
16.2 \\
15.8 \\
13.4 \\
11.9\end{array}$ & $\begin{array}{l}0.214 \\
0.286 \\
0.255 \\
0.271 \\
0.271 \\
0.266 \\
0.270\end{array}$ \\
\hline \multirow{2}{*}{ S. H. } & Control & $\stackrel{8.4}{\left.(26) / K_{\sigma}\right)}$ & 6.54 & 96.6 & 456 & 6.80 & 0.212 \\
\hline & $\begin{array}{r}15 \\
30 \\
50 \\
65 \\
95 \\
125\end{array}$ & $\begin{array}{r}7.6 \\
7.6 \\
7.6 \\
7.6 \\
7.4 \\
7.1\end{array}$ & $\begin{array}{l}33.6 \\
20.3 \\
16.8 \\
17.1 \\
19.7 \\
17.1\end{array}$ & $\begin{array}{l}88.1 \\
95.2 \\
95.2 \\
84.0 \\
77.6 \\
70.6\end{array}$ & $\begin{array}{l}384 \\
492 \\
462 \\
363 \\
341 \\
299\end{array}$ & $\begin{array}{l}38.1 \\
21.3 \\
17.7 \\
20.4 \\
25.4 \\
24.2\end{array}$ & $\begin{array}{l}0.230 \\
0.194 \\
0.206 \\
0.232 \\
0.228 \\
0.236\end{array}$ \\
\hline \multirow{2}{*}{ M.S. } & Control & $\stackrel{8.6}{\left(\mathrm{~K}_{x}\right)}$ & 7.12 & 85.2 & & 8.40 & \\
\hline & $\begin{array}{r}40 \\
100 \\
120 \\
150 \\
180\end{array}$ & $\begin{array}{c}8.3 \\
7.8 \\
7.6 \\
7.6 \\
7.6\end{array}$ & $\begin{array}{l}8.03 \\
15.3 \\
15.0 \\
14.4 \\
14.7\end{array}$ & $\begin{array}{l}88.4 \\
74.1 \\
82.9 \\
81.7 \\
91.5\end{array}$ & & $\begin{array}{l}9.10 \\
20.6 \\
18.1 \\
17.6 \\
16.1\end{array}$ & \\
\hline \multirow{2}{*}{ S. Z. } & $\begin{array}{c}\text { Control } \\
\text { PB } 2.0 \mathrm{Gm} .1\end{array}$ & $\begin{array}{c}8.4 \\
\text { (21 mg./Kg.) }\end{array}$ & 8.29 & 118 & & 7.20 & \\
\hline & $\begin{array}{r}30 \\
60 \\
90 \\
120\end{array}$ & $\begin{array}{l}7.9 \\
7.7 \\
7.2 \\
7.2\end{array}$ & $\begin{array}{c}14.2 \\
17.5 \\
21.4 \\
9.05\end{array}$ & $\begin{array}{c}101 \\
102 \\
116 \\
96.5\end{array}$ & & $\begin{array}{c}14.1 \\
17.2 \\
18.5 \\
9.80\end{array}$ & \\
\hline \multirow[t]{2}{*}{$\mathrm{M}_{45} \mathrm{~K}$} & $\begin{array}{l}\text { Control } \\
2.0 \mathrm{Gm}\end{array}$ & $\stackrel{10.5}{(21 \mathrm{mg} / \mathrm{Kg})}$ & 4.68 & 97.7 & 469 & 4.72 & 0.208 \\
\hline & $\begin{array}{r}20 \\
35 \\
50 \\
65 \\
80 \\
110 \\
140\end{array}$ & $\begin{array}{r}10.5 \\
10.3 \\
10.2 \\
10.1 \\
10.0 \\
9.8 \\
10.2\end{array}$ & $\begin{array}{c}13.2 \\
12.0 \\
10.4 \\
8.90 \\
8.72 \\
6.22 \\
4.53\end{array}$ & $\begin{array}{r}97.8 \\
88.6 \\
91.8 \\
108.0 \\
93.0 \\
84.9 \\
87.4\end{array}$ & $\begin{array}{l}345 \\
346 \\
375 \\
372 \\
383 \\
335 \\
328\end{array}$ & $\begin{array}{c}13.5 \\
13.5 \\
11.3 \\
8.25 \\
9.37 \\
7.33 \\
5.18\end{array}$ & $\begin{array}{l}0.284 \\
0.256 \\
0.245 \\
0.290 \\
0.243 \\
0.254 \\
0.266\end{array}$ \\
\hline
\end{tabular}

* Italicized values indicate peak responses to drug administration. 
TABLE I-Continued

\begin{tabular}{|c|c|c|c|c|c|c|c|}
\hline \multirow[b]{2}{*}{$\begin{array}{l}\text { Subject } \\
\text { (Age) }\end{array}$} & \multirow[b]{2}{*}{ Period } & \multirow[b]{2}{*}{ Purate } & \multicolumn{3}{|c|}{ Renal clearances } & \multicolumn{2}{|c|}{ Clearance ratios } \\
\hline & & & $C_{\text {urate }}$ & $C_{\text {In }}$ & $C_{P A B}$ & $\begin{array}{l}\mathrm{C}_{\text {urate }} / \mathrm{C}_{\text {In }} \\
\times \mathbf{1 0 0}\end{array}$ & $\mathrm{C}_{\mathrm{In} / \mathrm{C}_{\mathrm{PAB}}}$ \\
\hline \multirow{2}{*}{ P.S. } & $\begin{array}{c}\text { min. } \\
\text { Control }\end{array}$ & $\begin{array}{l}\text { mg. \% } \\
10.8\end{array}$ & $\begin{array}{c}c c . / \min . \\
5.04\end{array}$ & $\begin{array}{l}c c . / \min . \\
114\end{array}$ & $\begin{array}{c}c c . / \min . \\
437\end{array}$ & 4.40 & 0.261 \\
\hline & $\begin{array}{c}1.5 \mathrm{Gm} .1 . \\
30 \\
80 \\
110 \\
140\end{array}$ & $\begin{array}{c}\text { V. (17 mg./Kg.) } \\
10.0 \\
9.8 \\
9.6 \\
9.5\end{array}$ & $\begin{array}{l}12.8 \\
11.3 \\
10.9 \\
13.1\end{array}$ & $\begin{array}{l}101 \\
111 \\
107 \\
112\end{array}$ & $\begin{array}{l}337 \\
350 \\
335 \\
354\end{array}$ & $\begin{array}{l}12.7 \\
10.2 \\
10.2 \\
11.7\end{array}$ & $\begin{array}{l}0.300 \\
0.317 \\
0.320 \\
0.316\end{array}$ \\
\hline \multirow{2}{*}{$\underset{34}{\text { M.L. }}$} & Control & 9.2 & 9.02 & 149 & 702 & 6.10 & 0.212 \\
\hline & $\begin{array}{c}\text { PB 1.5 Gm. } 1.1 \\
15 \\
45 \\
75 \\
135\end{array}$ & $\begin{array}{c}\text { V. (16 mg./Kg.) } \\
8.9 \\
8.8 \\
8.6 \\
8.6\end{array}$ & $\begin{array}{l}28.7 \\
26.7 \\
27.1 \\
10.4\end{array}$ & $\begin{array}{l}146 \\
149 \\
125 \\
123\end{array}$ & $\begin{array}{l}505 \\
574 \\
576 \\
582\end{array}$ & $\begin{array}{l}19.0 \\
18.0 \\
21.7 \\
8.50\end{array}$ & $\begin{array}{l}0.289 \\
0.260 \\
0.217 \\
0.212\end{array}$ \\
\hline \multirow{2}{*}{ C. G. } & Control & 9.2 & 2.79 & 85.1 & 316 & 3.30 & 0.270 \\
\hline & $\begin{array}{c}30 \\
60 \\
90 \\
120\end{array}$ & $\begin{array}{c}\text { v. (14 mg./Kg.) } \\
9.2 \\
9.2 \\
9.2 \\
9.2\end{array}$ & $\begin{array}{l}4.91 \\
5.33 \\
5.03 \\
4.97\end{array}$ & $\begin{array}{l}79.9 \\
85.4 \\
89.4 \\
85.6\end{array}$ & $\begin{array}{l}226 \\
236 \\
249 \\
237\end{array}$ & $\begin{array}{l}6.20 \\
6.20 \\
5.60 \\
5.80\end{array}$ & $\begin{array}{l}0.353 \\
0.362 \\
0.359 \\
0.362\end{array}$ \\
\hline \multirow[t]{2}{*}{$\underset{58}{\text { M. D. }}$} & $\begin{array}{c}\text { Control } \\
\text { PB } 1.0 \mathrm{Gm}\end{array}$ & $\stackrel{8.1}{\left.\stackrel{8.1}{m g} / K_{g}\right)}$ & 8.48 & 83.2 & 419 & 10.2 & 0.199 \\
\hline & $\begin{array}{c}15 \\
45 \\
75 \\
105 \\
135 \\
165 \\
195\end{array}$ & $\begin{array}{c}.(14 \mathrm{mg} . / \mathrm{Kg} .) \\
8.4 \\
8.3 \\
8.1 \\
7.9 \\
7.8 \\
7.8 \\
7.6 \\
7.5\end{array}$ & $\begin{array}{c}15.3 \\
11.8 \\
12.5 \\
9.77 \\
9.56 \\
9.94 \\
10.4\end{array}$ & $\begin{array}{l}79.5 \\
78.0 \\
81.0 \\
78.2 \\
80.0 \\
79.1 \\
83.8\end{array}$ & $\begin{array}{l}326 \\
335 \\
327 \\
321 \\
366 \\
377\end{array}$ & $\begin{array}{l}19.3 \\
15.1 \\
15.4 \\
12.5 \\
12.0 \\
12.6 \\
12.4\end{array}$ & $\begin{array}{l}0.244 \\
0.233 \\
0.248 \\
0.244 \\
0.218 \\
0 . \overline{222}\end{array}$ \\
\hline \multirow[t]{2}{*}{ P. M. $†$} & Control & $\frac{7.3}{\mathrm{~V}}$ & 6.84 & 124 & 311 & 5.50 & 0.399 \\
\hline & $\begin{array}{c}\text { PB } 1.0 \text { Gm. } \\
60 \\
90 \\
120 \\
150\end{array}$ & $\begin{array}{c}\text { v. (IZ mg./Kg.) } \\
7.3 \\
7.2 \\
7.2 \\
7.2\end{array}$ & $\begin{array}{l}7.68 \\
9.60 \\
8.20 \\
5.97\end{array}$ & $\begin{array}{c}106 \\
114 \\
132 \\
96.8\end{array}$ & $\begin{array}{l}232 \\
271 \\
308 \\
235\end{array}$ & $\begin{array}{l}7.20 \\
8.40 \\
6.20 \\
6.20\end{array}$ & $\begin{array}{l}0.457 \\
0.421 \\
0.428 \\
0.412\end{array}$ \\
\hline
\end{tabular}

† In addition to gout this patient had coronary heart disease with mild congestive failure.

for us by Dr. J. J. Burns of the New York University Research Division at Goldwater Memorial Hospital. This was accomplished by extracting phenylbutazone from acidified plasma into heptane. It was then returned to aqueous alkali in which optical density was determined in a UV spectrophotometer at a wave length of $265 \mathrm{~m} \mu$.

\section{RESULTS}

The acute effects of intravenous phenylbutazone administration upon renal urate and inulin clearances and plasma urate concentrations in ten subjects are presented in Table I. A significant elevation of the urate clearance, $C$ urate, and of the ratio of urate clearance to inulin clearance times $100, \mathrm{C}$ urate $/ \mathrm{C}_{\mathrm{In}}$, followed the injection of phenylbutazone in every instance. $\mathrm{C}$ urate rose from a mean control value of $6.3 \mathrm{cc}$. per min. to a mean peak value of $19.3 \mathrm{cc}$. per min., and $C$ urate/ $C_{\text {In }}$ rose from a mean control of 6.04 to a mean peak of 19.5. In the five subjects receiving larger doses of the drug ( $>20 \mathrm{mg}$. per body weight), $\mathrm{C}$ urate rose from a mean value of 6.17 to a mean peak value of $24.2 \mathrm{cc}$. per min., and $\mathrm{C}$ urate/ $\mathrm{C}_{\text {In }}$ rose from a mean of 6.23 to 25.4. In the five subjects receiving the drug in doses less than 20 mg. per $\mathrm{Kg}$. body weight, $\mathrm{C}$ urate rose from a mean control of 6.43 to a mean peak of $14.4 \mathrm{cc}$. per min.; the corresponding $\mathrm{C}$ urate/ $\mathrm{C}_{\text {In }}$ rose from 5.90 to 16.4 .

Of the five subjects receiving the drug in dosages $>20 \mathrm{mg}$. per $\mathrm{Kg}$ body weight and showing a more marked uricosuric response, four exhibited a fall in plasma urate of $1.0 \mathrm{mg}$. per cent or more. Only one of the five subjects receiving phenylbutazone in dosages $<20 \mathrm{mg}$. per $\mathrm{Kg}$. body weight, with less marked uricosuria, had a decline 


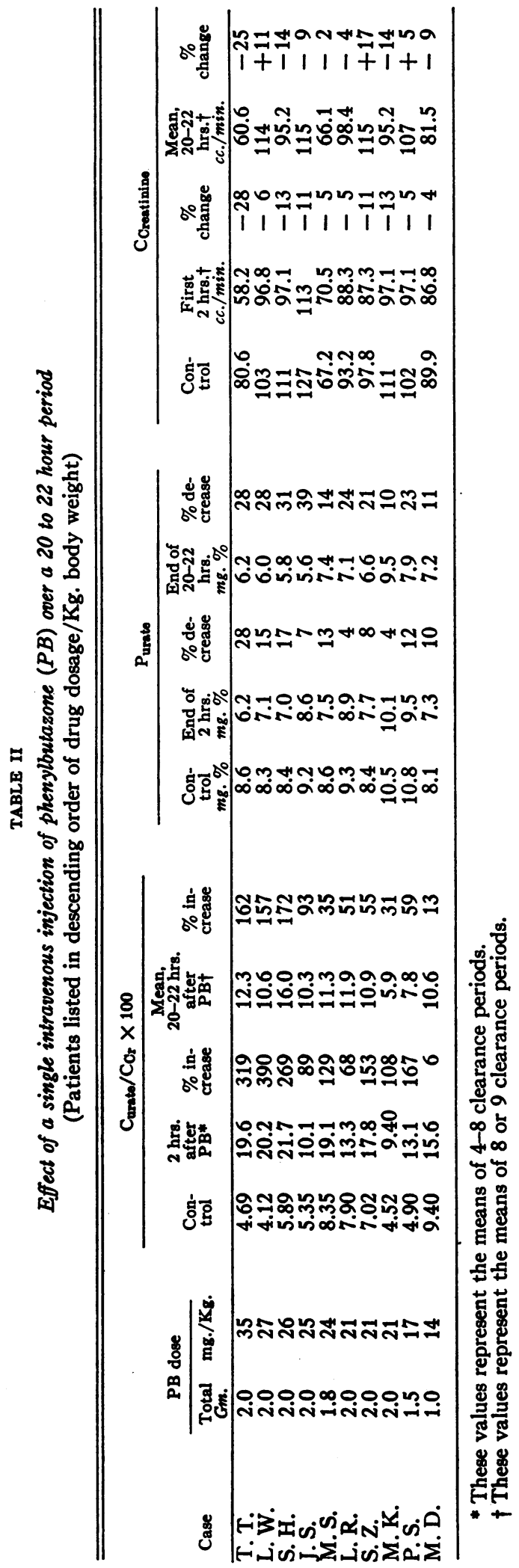

in serum urate concentration of more than $1 \mathrm{mg}$. per cent during the two-hour observation period.

The continued effects of a single intravenous injection of phenylbutazone on $C$ urate and $C_{C r}$ for a period of 20 to 22 hours are summarized in Figure 1 and Table II. It is evident that the peak elevation in $\mathrm{C}$ urate $/ \mathrm{C}_{\mathrm{Cr}}$ occurred during the first two to four hours after drug administration, ranging from +64 per cent to +390 per cent with a mean of +176 per cent. A significant elevation of this ratio continued for the subsequent 20 to 22 hours, ranging from +13 per cent to +172 per cent and averaging +87.8 per cent. This effect again was more marked with the higher drug dosages. In all of the subjects a significant fall in plasma urate concentration occurred by the end of 20 to 22 hours, the mean fall being from $9.0 \mathrm{mg}$. per cent to $6.9 \mathrm{mg}$. per cent (Table II). The magnitude of this response could be correlated with the mean rise in $\mathrm{C}$ urate/ $\mathrm{C}_{\mathrm{Or}}$ during this time interval.

The effects of orally administered phenylbutazone, given in a daily dosage of $800 \mathrm{mg}$., upon the 24-hour urinary urate excretion and the plasma urate concentration are summarized in Table III. The mean control urinary urate excretion in the eight gouty patients studied ranged from 198 to $658 \mathrm{mg}$. per 24 hours. In four subjects, uricosuria appeared during the first day of drug administration, in two subjects on the second day, and in two subjects on the third day. The peak uricosuria occurred on the first day in one patient, on the second day in one, and on the fourth day in six. In all save one subject there was an overall increase in urinary urate excretion throughout the total period of medication, the mean increase ranging from +23 per cent to +168 per cent. The one subject who did not show a continued uricosuric response, Case R. R., had received phenylbutazone elsewhere for several months shortly before instituting the present study. In this subject, increased urinary urate excretion occurred on the first day of medication only, $632 \mathrm{mg}$. per 24 hours, as compared to a control value. of $534 \mathrm{mg}$. In spite of absence of any further uricosuric action of phenylbutazone, a plasma urate concentration of $4.6 \mathrm{mg}$. per cent was observed on the fourth day, the control value being $8.1 \mathrm{mg}$. per cent. 

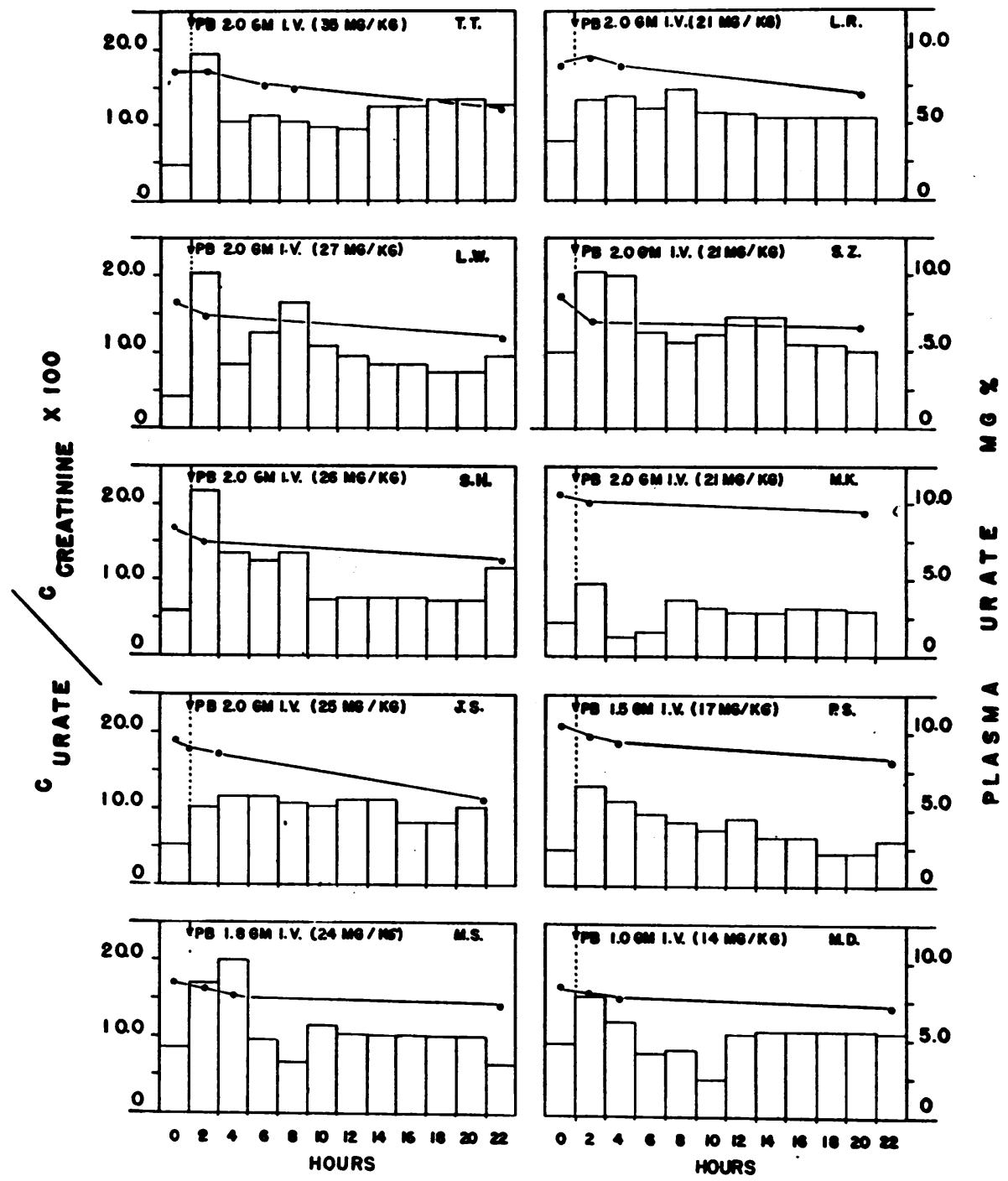

Fig. 1. The Effects of a Single Intravenous Injection of Phenylbutazone (Indicated by Arrow) on C urate/C Crgatnine (Bars) and Plasma Urate Concentrations (Points Connected by Line) over Period of 20 to 22 Hours in Ten Gouty SUBJECTS

The relationship between phenylbutazone plasma concentrations and uricosuria was studied in five gouty subjects. In Figure 2 (Cases L. R. and J. S.), the effect of a gradual rise in plasma phenylbutazone concentrations upon the $\mathrm{C}$ urate/ $\mathrm{C}_{\text {In }}$ is illustrated. It is evident that significant elevation of the $C$ urate/ $C_{\text {In }}$ above control values starts at plasma phenylbutazone concentrations of about $10 \mathrm{mg}$. per cent, and that stepwise elevation of the ratio occurs with rising concentrations of phenylbutazone in the plasma. The slow decline in plasma concentrations of the drug and the continued elevation of the $\mathrm{C}$ urate/ $\mathrm{C}_{\mathrm{Cr}}$ for 20 to 22 hours are apparent.

In the three subjects given rapid intravenous infusions of $2 \mathrm{Gm}$. phenylbutazone (21 to $27 \mathrm{mg}$. per $\mathrm{Kg}$. body weight) the plasma phenylbutazone concentrations averaged $20 \mathrm{mg}$. per cent approximately five minutes after completion of the infusion. Significant elevations of $\mathrm{C}$ urate and $C$ urate/ $C_{l n}$ occurred in each instance during the first 20-minute period (Table I, Cases M. K., L. W., and S. H.).

The glomerular filtration rate, as measured by 
inulin clearance over a two-hour period, was not affected by phenylbutazone in six subjects but was somewhat lowered in four (Table I). In subject M. L., the GFR fell to 129 cc. per min. from a control value of $149 \mathrm{cc}$. per min. approximately 75 minutes after drug administration. In subject $P$. M., with a control value of $124 \mathrm{cc}$. per min., the GFR was 106 cc. per min. some 60 minutes after drug administration. In cases S. $Z$. and S. H., the GFR declined from 118 to $101 \mathrm{cc}$. per min. and from 96.6 to $70.6 \mathrm{cc}$. per min. 30 and 125 minutes after drug administration, respectively. These represent depressions in GFR of 14 to 31 per cent, with no correlation between changes in GFR and phenylbutazone dosage. A slight depression of the endogenous creatinine clearance ( 10.7 to 27.8 per cent) occurred during the first two hours in five subjects (M. K., J. S., S. H., T. T., and S. Z.). This effect continued in three of these subjects for 20 to 22 hours (Table II). The most marked decline was noted in subject $T$. T., who received the largest dose of phenyl-

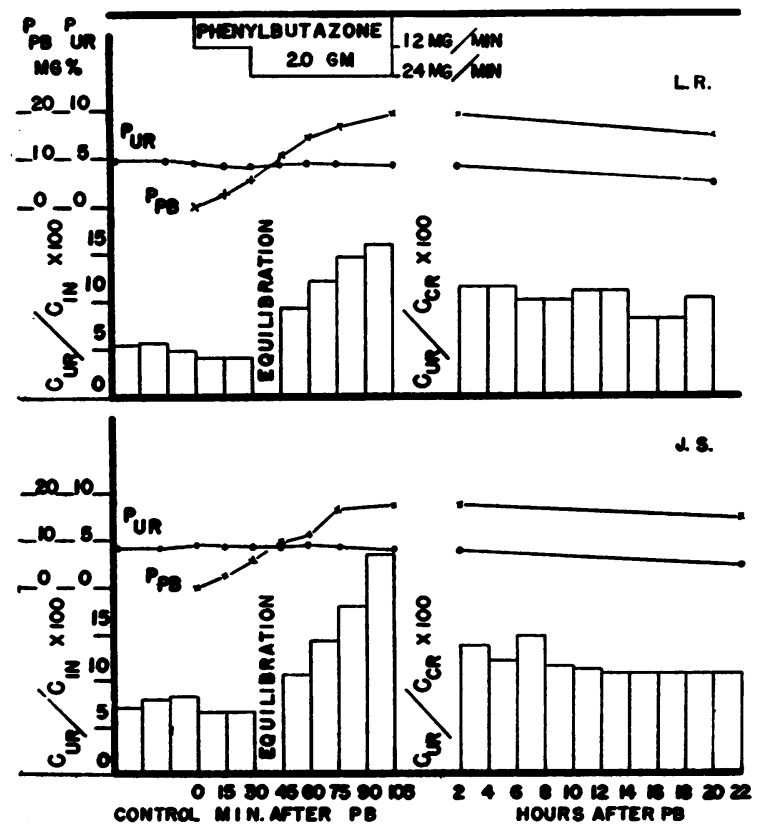

Fig. 2. The Effects of a Gradual Rise in Plasma Phenylbutazone Concentration (Crosses), Brought About by Slow Intrafenous Infusion of the Drug, oN C urate/C Crantaranz (Bars) and Plasma Urate Concentrations (Dots Connected by Line)

A uricosuric effect was not elicited until the plasma phenylbutazone concentration reached approximately 10 mg. per cent. butazone ( $35 \mathrm{mg}$. per $\mathrm{Kg}$. body weight), with a depression of $\mathrm{C}_{\mathrm{Cr}}$ from a control of $80.6 \mathrm{cc}$. per $\mathrm{min}$. to a two-hour value of $58.2 \mathrm{cc}$. per min. and a mean 20 to 22 hour value of $60.6 \mathrm{cc}$. per $\mathrm{min}$.

Depression of the $P A H$ clearance occurred in all subjects so studied, the mean control value of $495 \mathrm{cc}$. per min. falling to a mean minimum value of $326 \mathrm{cc}$. per min. (Table I). Concomitant elevations of the filtration fraction, $\mathrm{C}_{\mathrm{In}} / \mathrm{C}_{\mathbf{P A H}}$, occurred in all subjects. This effect upon $C_{\mathbf{P A B}}$ was noted at all utilized dosages of the drug from the time of the first urine collection period after drug administration until termination of the study.

In two of the subjects, S. Z. and M. S., the effect upon $T m_{P A B}$ of intravenously administered phenylbutazone in dosages of 21 and $24 \mathrm{mg}$. per $\mathrm{Kg}$. body weight, respectively, was determined. The results were striking: $\mathrm{Tm}_{\mathbf{P A B}}$ fell from control values of 75.7 and $61.4 \mathrm{mg}$. per min. to 12.9 and $14.0 \mathrm{mg}$. per min., respectively.

The effects of intravenous phenylbutazone administration on the urinary excretion of sodium, potassium, chloride and inorganic phosphate in three gouty subjects are presented in Figure 3. All showed definite inhibition of sodium and chloride excretion, during drug administration which persisted for three days after discontinuance of medication. Thus, in subject O. G., the mean sodium excretion fell from a control value of $0.81 \mathrm{Gm}$. per day to $0.37 \mathrm{Gm}$. per day during medication, rising to $0.61 \mathrm{Gm}$. per day after discontinuance of the drug. The corresponding figures for chloride excretion were 1.63, 0.92, and $1.20 \mathrm{Gm}$. per day, respectively. In subject L. W. sodium excretion fell from $2.20 \mathrm{Gm}$. per day to 1.13 and $1.22 \mathrm{Gm}$. per day during and after medication. The corresponding chloride excretion was $3.61,1.80$, and $2.08 \mathrm{Gm}$. per day. In subject A. $R$., the values for sodium excretion were 1.25 in the control period, and 0.40 and $1.02 \mathrm{Gm}$. per day; those for chloride excretion were $2.10,0.98$, and $2.01 \mathrm{Gm}$. per day, respectively. No consistent or significant effect was observed on potassium and inorganic phosphate excretion, or on the clearance of endogenous creatinine in these three subjects.

Figure 4 summarizes the diurnal variations in the clearance ratios $\mathrm{C}_{\mathrm{Na}} / \mathrm{C}_{\mathrm{Or}}, \mathrm{C}_{\mathrm{K}} / \mathrm{C}_{\mathrm{Or}}, \mathrm{C}_{\mathrm{Cl}} / \mathrm{C}_{\mathrm{Or}}$, $\mathrm{C}_{\mathrm{P}} / \mathrm{C}_{\mathrm{Or}}$, and $\mathrm{C}$ urate/ $\mathrm{C}_{\mathrm{Or}}$ in subject $\mathrm{O}$. $\mathrm{G}$. during 
control, medication, and post-medication periods. The depression of $\mathrm{C}_{\mathrm{Na}} / \mathrm{C}_{\mathrm{Or}}$ and $\mathrm{C}_{\mathrm{Cl}} / \mathrm{C}_{\mathrm{Cr}}$ and the elevation of $\mathrm{C}$ urate/ $\mathrm{C}_{\mathrm{or}}$ during the medication and post-medication periods are obvious. Significant changes in the $C_{K} / C_{C r}$ and $C_{P} / C_{C r}$ were not noted. Essentially similar results were obtained for the other two subjects. Significant changes in body weight and 24-hour urine volume were not noted during these studies.

In subject $\mathrm{L}$. W., the plasma sodium concentration rose from a control value of $145 \mathrm{mEq}$. per $\mathrm{L}$. to $156 \mathrm{mEq}$. per L. six hours after the first dose of phenylbutazone. This cannot be accounted for by the very small amount of sodium (sodium salt of phenylbutazone) infused. Return to the control value occurred by the next 24 hours. In subject $\mathrm{O}$. G., the plasma sodium concentration rose from a control value of $141 \mathrm{mEq}$. per L. to 145 $\mathrm{mEq}$. per $\mathrm{L}$. and $150 \mathrm{mEq}$. per L., six and twelve hours after start of medication. Normal values were regained 18 hours later. This phenomenon was not observed in subject $A$. $R$.

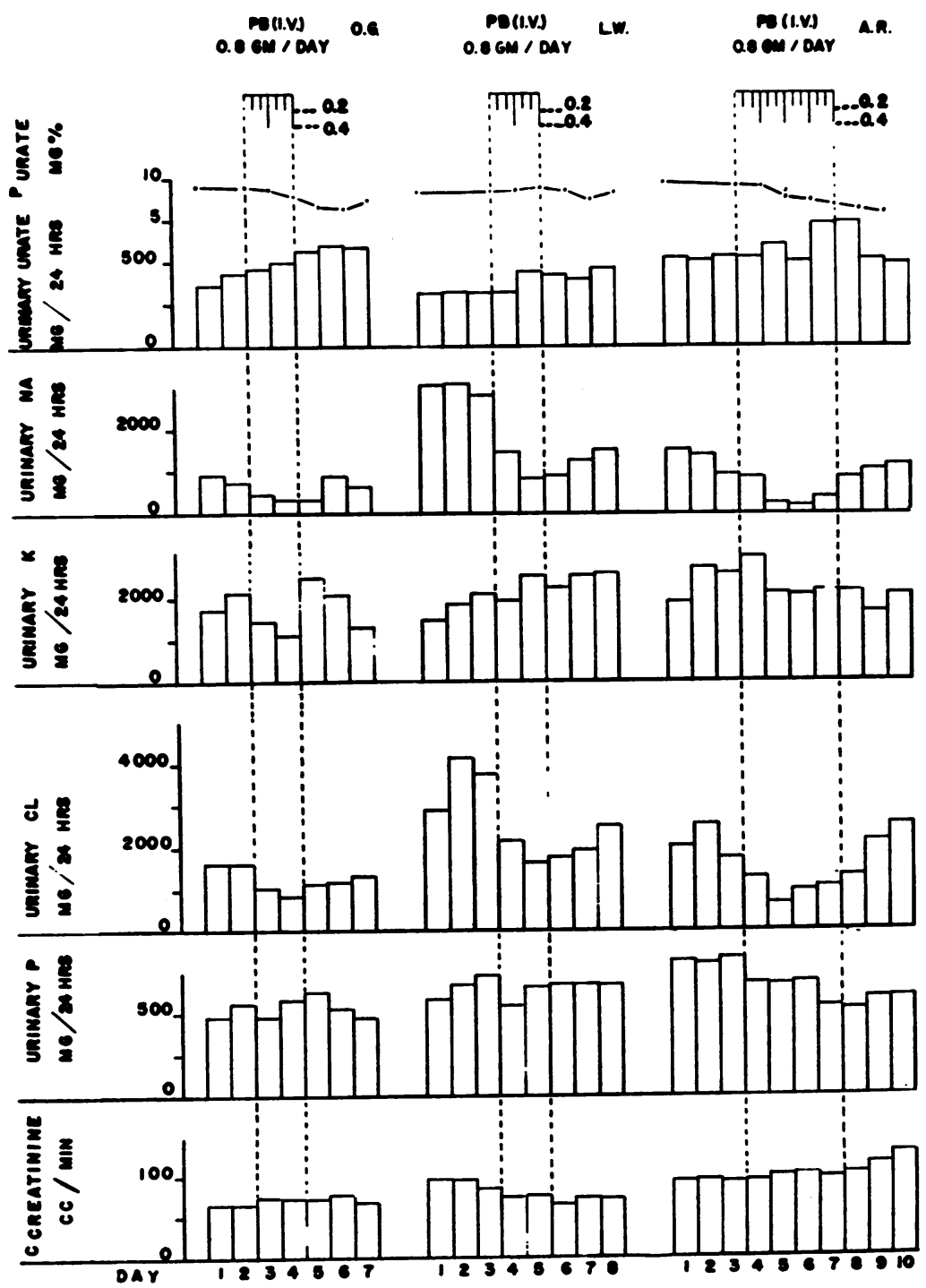

Fig. 3. The Effects of Intratenous Injections or Pegenylbutazone upon the Urinary Excretion of Sodium, Potassium, Chloride, Inorganic Phosphate and Uric Acm, and upon the Endogrnous Creatinine ClenrANCE in Threg Gouty SUbJects 
TABLE III

Effect of orally administered phenylbutazone $(800 \mathrm{mg} . /$ day $)$ on urinary urate excretion and plasma urate concentration in eight gouty subjects

\begin{tabular}{|c|c|c|c|c|c|c|c|c|c|c|c|c|}
\hline \multirow{2}{*}{ 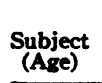 } & \multirow[b]{2}{*}{ Tophi } & \multirow[b]{2}{*}{ CInulin } & \multicolumn{3}{|c|}{ Control period } & \multicolumn{7}{|c|}{ Days on phenylbutazone } \\
\hline & & & & Mean & Range & 1 & 2 & 3 & 4 & 5 & 6 & 7 \\
\hline$T_{61} . T$. & +++ & $\begin{array}{c}c c . / \min . \\
76.8\end{array}$ & $\stackrel{\mathrm{U}}{\mathrm{P}}$ & $\begin{array}{r}198 \\
9.1\end{array}$ & $184-227$ & $\begin{array}{l}313^{*} \\
8.4\end{array}$ & $\begin{array}{r}473 \\
8.0\end{array}$ & $\begin{array}{r}413 \\
7.9\end{array}$ & $\begin{array}{c}938 \dagger \\
7.2\end{array}$ & $\begin{array}{r}680 \\
6.7\end{array}$ & & \\
\hline L.W. & 0 & 92.8 & $\begin{array}{l}\mathrm{U} \\
\mathrm{P}\end{array}$ & $\begin{array}{r}306 \\
6.6\end{array}$ & $243-328$ & 316 & 337 & $542^{*}$ & $\begin{array}{l}812 \dagger \\
4.7\end{array}$ & 796 & $\begin{array}{r}704 \\
5.3\end{array}$ & \\
\hline$\underset{46}{\text { O. G. }}$ & 0 & 74.1 & $\stackrel{\mathrm{U}}{\mathbf{P}}$ & $\begin{array}{r}457 \\
7.3\end{array}$ & $393-498$ & $628^{*}$ & $\begin{array}{r}756 \\
5.4\end{array}$ & 777 & $\begin{array}{l}796 \dagger \\
4.4\end{array}$ & & & \\
\hline$\underset{49}{H . S .}$ & + & 89.0 & $\begin{array}{l}\mathbf{U} \\
\mathbf{P}\end{array}$ & $\begin{array}{r}658 \\
8.9\end{array}$ & $618-699$ & $843^{*}$ & 1028 & 880 & $\begin{array}{r}1170 \dagger \\
4.7\end{array}$ & & & \\
\hline L. G. & 0 & 111 & $\stackrel{\mathrm{U}}{\mathrm{P}}$ & $\begin{array}{r}640 \\
7.4\end{array}$ & $547-742$ & $\begin{array}{r}532 \\
7.0\end{array}$ & $\begin{array}{c}1289 \dagger \\
7.3\end{array}$ & $\begin{array}{r}869 \\
7.8\end{array}$ & $\begin{array}{r}840 \\
5.6\end{array}$ & $\begin{array}{r}1080 \\
4.4\end{array}$ & 1083 & $\begin{array}{r}740 \\
3.9\end{array}$ \\
\hline$\underset{42}{\text { M. H. }}$ & 0 & 74.5 & $\stackrel{\mathrm{U}}{\mathrm{P}}$ & $\begin{array}{r}489 \\
8.7\end{array}$ & $466-513$ & $\begin{array}{r}505 \\
8.1\end{array}$ & $\begin{array}{l}653^{*} \\
7.3\end{array}$ & $\begin{array}{r}632 \\
6.3\end{array}$ & $\begin{array}{c}911 \dagger \\
4.1\end{array}$ & & & \\
\hline$\underset{64}{\text { G. B. }}$ & $+++t$ & 48.9 & $\stackrel{\mathrm{U}}{\mathrm{P}}$ & $\begin{array}{r}457 \\
9.8\end{array}$ & $430-511$ & 402 & 394 & $554^{*}$ & $\begin{array}{c}905 \dagger \\
7.5\end{array}$ & & & \\
\hline$\underset{44}{R_{.} R}$ & 0 & - & $\stackrel{\mathrm{U}}{\mathrm{P}}$ & $\begin{array}{c}534 \\
8.1\end{array}$ & $480-582$ & $632 \dagger$ & 417 & 242 & $\begin{array}{r}595 \\
4.6\end{array}$ & 587 & 470 & $\begin{array}{r}504 \\
5.3\end{array}$ \\
\hline
\end{tabular}

* Initial uricosuria.

t Maximum uricosuria noted.

$U=$ urinary urate, $\mathrm{mg} . / 24$ hours.

$\mathbf{P}=$ plasma urate, $\mathbf{m g}$. \%.

Significant changes in plasma potassium, inorganic phosphate and chloride concentrations were not noted in any of the three subjects.

The effect of simultaneous administration of phenylbutazone and probenecid (Benemid) upon urinary urate excretion was studied in seven subjects. The administration of phenylbutazone orally, $0.2 \mathrm{Gm}$. three times a day, to three subjects during effective probenecid uricosuria (1.0 $\mathrm{Gm}$. probenecid per day) resulted in a moderate depression of the 24-hour urate excretion for one or two days. This was followed by return to previous levels of urate excretion in spite of continued simultaneous administration of both drugs.

TABLE IV

The effect of simultaneous administration of benemid ( $B E N)$ and phenylbutazone $(P B)$ upon the renal clearances of urate and inulin*

\begin{tabular}{|c|c|c|c|c|c|c|c|c|c|c|c|}
\hline \multirow[b]{2}{*}{ Subject } & \multicolumn{3}{|c|}{ Control period } & \multicolumn{4}{|c|}{ Post-medication period I } & \multicolumn{4}{|c|}{ Post-medication period II } \\
\hline & $\mathbf{C}_{\mathbf{I n}}$ & Curate & $\begin{array}{c}C_{\text {uratog }} / C_{\text {In }} \\
\times 100\end{array}$ & $\begin{array}{l}\text { Drug } \\
\text { given }\end{array}$ & $C_{\text {In }}$ & $C_{\text {urato }}$ & $\mathrm{C}_{\mathbf{\text { ureta }}} / \mathrm{C}_{\mathrm{In}}$ & $\begin{array}{l}\text { Drug } \\
\text { given }\end{array}$ & $\mathbf{C}_{\text {In }}$ & $C_{\text {urate }}$ & $\mathrm{C}_{\text {urato }} / \mathrm{C}_{\mathrm{In}}$ \\
\hline & & $c c . / \min$. & & $\begin{array}{l}m_{g} / K_{g} \\
\text { (BEN) }\end{array}$ & & $c c . / \min$. & & $\begin{array}{c}m g . / K_{g} \\
\text { (PB) }\end{array}$ & cc./min. & $c c . / \min$. & \\
\hline P. C. & 89.3 & 5.54 & 6.19 & 20.0 & 83.7 & 19.2 & 22.9 & 14.0 & 77.0 & 13.2 & 17.2 \\
\hline I. G. & 109 & 8.05 & 7.38 & $\begin{array}{c}\text { (BEN) } \\
20.0\end{array}$ & 111 & 25.4 & 22.9 & $\begin{array}{l}\text { (PB) } \\
13.3\end{array}$ & 98.1 & 20.1 & 20.5 \\
\hline C. G. & 85.1 & 2.79 & 3.28 & $\begin{array}{l}\text { (PB) } \\
14.0\end{array}$ & 85.1 & 5.06 & 5.95 & $\begin{array}{c}\text { (BEN) } \\
20.0\end{array}$ & 85.0 & 10.4 & 12.3 \\
\hline P. M. & 110 & 6.85 & 6.23 & $\begin{array}{l}\text { (PB) } \\
12.0\end{array}$ & 95.0 & 7.86 & 8.28 & $\begin{array}{c}\text { (BEN) } \\
20.0\end{array}$ & 91.0 & 21.4 & 23.6 \\
\hline
\end{tabular}

\footnotetext{
* All clearance values represent the mean of at least three clearance periods.
} 


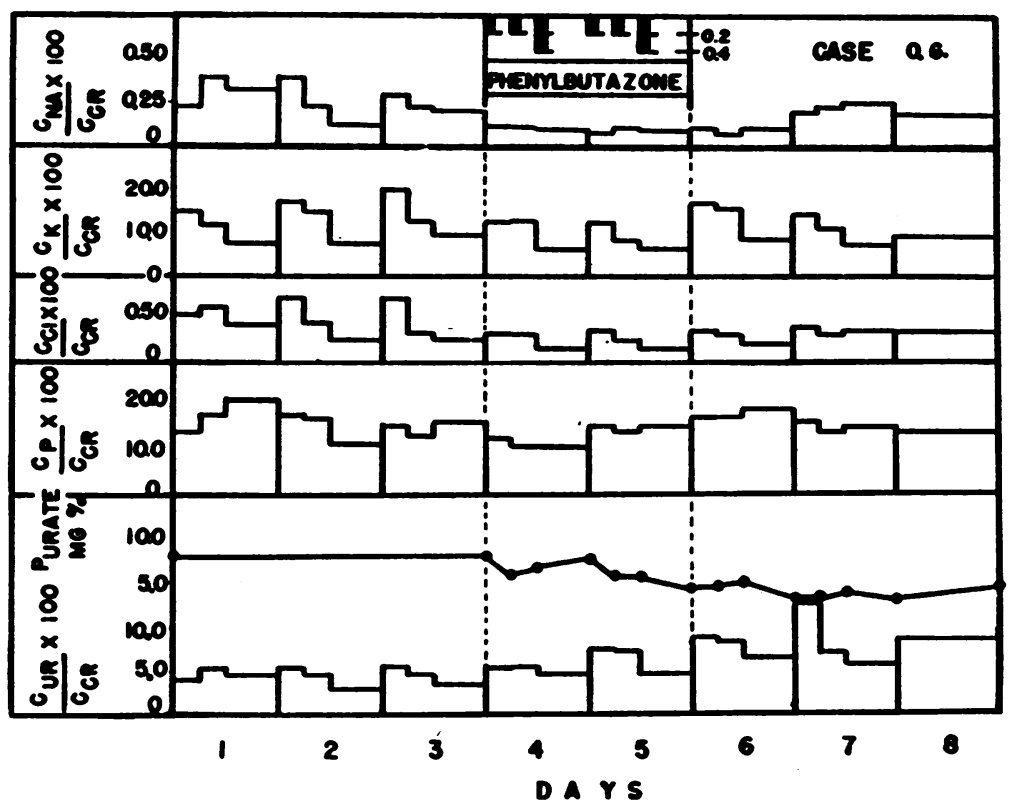

Fig. 4. The Effects of Intravenous Injections of Phenylbutazone upon the Diurnal Variations in Clearance Ratios of $\mathrm{C}_{\mathrm{ka}} / \mathrm{C}_{\mathrm{cr}}, \mathrm{C}_{\mathrm{z}} / \mathrm{C}_{\mathrm{cr}}$, $\mathrm{C}_{\mathrm{C} 1} / \mathrm{C}_{\mathrm{CR}}, \mathrm{C}_{\mathrm{P}} / \mathrm{C}_{\mathrm{CR}}$, and $\mathrm{C}$ urate/Cor

In four subjects the acute effects of concomitant intravenous administration of both drugs upon inulin and urate clearances were determined by giving $1 \mathrm{Gm}$. of probenecid prior to phenylbutazone in two of the subjects, and subsequent to phenylbutazone in the remaining two. The results are presented in Table IV. Subjects P. C. and I. G. received intravenous probenecid first. Their $C$ urate/ $C_{\text {In }}$ ratios rose from 6.19 and 7.38 to 22.9 and 22.9 , respectively, without any changes in $\mathrm{C}_{\mathrm{In}}$. When phenylbutazone was then administered, slight depressions in $\mathrm{C}_{\text {In }}$ occurred. The slight declines noted in $\mathrm{C}$ urate/ $\mathrm{C}_{\text {In }}$ may be explained on the basis of the time required for the experimental procedure, the peak uricosuric effect of probenecid having subsided. In subjects $C$. G. and P. M., the prior administration of phenylbutazone resulted in a slight decline of $C_{I n}$ in $P$. M. only, and a slight elevation of $C$ urate/ $C_{\text {In }}$ in both. Subsequent probenecid administration resulted in additional elevations of these ratios without further changes in $C_{\text {In. }}$. Marked interference with probenecid uricosuria by phenylbutazone administration is not apparent from these studies.
Untoward effects attributable to phenylbutazone administration were not observed in any of the subjects included in this study.

DISCUSSION

\section{Uricosuric effect}

Phenylbutazone in adequate dosage increased the urate clearance and enhanced urinary urate excretion in most gouty subjects studied. The uricosuric effect, in general, appeared to be related to the plasma phenylbutazone concentration. In the patients studied a plasma phenylbutazone concentration of approximately $10 \mathrm{mg}$. per cent was required to induce uricosuria and the uricosuric effects increased roughly in proportion to further elevation of drug levels in the blood. Immediate uricosuric plasma concentrations are readily achieved by intravenous injection of adequate doses. Thus, in three subjects, given $2.0 \mathrm{Gm}$. of phenylbutazone intravenously, the initial plasma drug levels five minutes after injection averaged $20 \mathrm{mg}$. per cent and were still as high as $14 \mathrm{mg}$. per cent 20 hours later. In most subjects receiving the usual daily dose, $0.8 \mathrm{Gm}$. by mouth, the plasma concentration of the drug, while variable from individual to individual, (6) 
usually ranges from $6 \mathrm{mg}$. to $15 \mathrm{mg}$. per cent. For example, in subject M. H. (Table III), who received this dosage daily by mouth, the plasma concentrations of phenylbutazone were found to be $6.9,10.6,14.4$, and $15.2 \mathrm{mg}$. per cent on the four successive days of administration. Uricosuria started on the second day of medication, when the plasma phenylbutazone concentration was $10.6 \mathrm{mg}$. per cent, and became more marked as the plasma drug levels rose.

The data indicate that the uricosuric effect of phenylbutazone is attributable to inhibition of tubular reabsorption of filtered urate. C urate/ $\mathrm{C}_{\text {In }}$ was found to be consistently and significantly elevated by the drug in adequate plasma concentration. The plasma urate in gout is virtually completely filtrable at the glomerulus, so far as we have been able to determine by ultrafiltration studies to be reported in detail elsewhere.

The observations of Burns and his associates $(6,7,8)$ on the disposition of phenylbutazone in man appear to shed some light on the relationship between plasma phenylbutazone concentration and inhibition of tubular reabsorption of urate. These investigators found that, at plasma phenylbutazone concentrations less than $10 \mathrm{mg}$. per cent, the drug is almost completely bound to plasma proteins; at levels of $10 \mathrm{mg}$. per cent only 2 per cent of the drug is filtrable and, as the plasma concentration rises, more and more of the drug is filtrable. Since very little unmetabolized phenylbutazone is found in the urine ( 7$)$, the freely filtrable fraction of the drug must be practically completely reabsorbed by the renal tubules. This reabsorptive process may interfere in some way with the transfer mechanisms for urate reabsorption.

The inhibition of tubular reabsorption of urate by phenylbutazone appears to be significantly less than that of comparable doses of probenecid. Thus in acute experiments with probenecid (4), doses of $20 \mathrm{mg}$. per $\mathrm{Kg}$. body weight produced a mean rise in $\mathrm{C}$ urate from a control of $8.55 \mathrm{cc}$. per min. to $32.9 \mathrm{cc}$. per min., and a rise in $\mathrm{C}$ urate/ $\mathrm{C}_{\text {In }}$ from a mean control value of 7.10 to 33.7. Under the same experimental conditions, phenylbutazone in doses greater than $20 \mathrm{mg}$. per $\mathrm{Kg}$. body weight produced much lower peak responses (Table I).

Because of the more pronounced and regular uricosuric effect of probenecid, and its insignificant predisposition to serious toxic reactions, probenecid is more suitable for protracted use as a uricosuric agent in chronic gout than phenylbutazone, which is not recommended for the purpose. Phenylbutazone may be employed to advantage in short-term therapy to control acute gouty seizures in many cases, however, since this action of the drug does not depend upon its uricosuric effect $(1,2)$.

\section{Fall in plasma urate concentration and its rela- tionship to uricosuria}

In accordance with the general experience, we find that phenylbutazone in adequate dosage effects a significant fall in plasma urate levels. The question has been raised whether such declines can reasonably be accounted for by the concomitant increase, if any, in urinary urate excretion. Kidd, Boyce, and Freyberg (9), for example, noted a distinct decrease in plasma urate in 15 gouty subjects receiving 400 to $800 \mathrm{mg}$. phenylbutazone per day, but in nine of these patients, apparently on uncontrolled diets, they were unable to demonstrate a significant increase in urinary urate excretion.

Any attempt to relate changes in plasma urate concentration to the quantity of urate excreted in the urine is, for the present, subject to large error since this relationship is markedly affected by such variables as the size of the readily mobilizable tissue deposits (miscible pool) of urate in individual gouty subjects, fluctuations in urate biosynthesis due to intrinsic and extrinsic (dietary) causes, alterations in plasma volume, variations in renal clearance of urate, etc. If the readily mobilizable tissue deposit of urate is very small, or has been markedly depleted by prior treatment with a uricosuric agent, exhibition of any uricosuric drug will elicit only a small and transitory increase in urinary urate excretion and this will be accompanied by a distinct and sustained fall in plasma urate levels, reflecting the failure of replenishment from mobilizable tissue (tophaceous) reserves. This has been our invariable experience with probenecid and the observations on Case $R$. $R$. in the present study (Table III) would suggest that the same applies to phenylbutazone.

In our patients receiving phenylbutazone intravenously, the fall in plasma urate concentra- 
tion and the extent of uricosuria were consistently greater in those given larger doses in terms of mg. per $\mathrm{Kg}$. body weight. The correlation between uricosuric effect and fall in plasma urate levels in these subjects was reasonably good (Tables I and II, Figure 1). In the patients given phenylbutazone orally, the uricosuric response in most instances also seemed adequate to account for the fall in plasma urate levels but several exceptions were noted. Case $R$. $R$. (Table III) has already been commented upon. In Cases A. R. (Figure 3) and M. H. (Table III) there was a distinct fall in plasma urate concentration before the urinary urate excretion was appreciably increased. A factor which played a role in lowering the plasma urate concentration in Case $\mathrm{M}$. H. was the expansion of extracellular fluid volume consequent upon retention of salt and water. In this subject measurement of T-1824 space revealed a 47 per cent increase 96 hours after medication was begun, although the 48-hour measurement showed no increase. Chenkin et al. (10) have demonstrated expansions in plasma volume as great as 50 per cent in some patients receiving the drug.

Other possible explanations for a fall in plasma urate concentration apparently disproportionate to the uricosuric effect of phenylbutazone include depression of urate biosynthesis, accelerated removal of urate from the blood by excretory pathways other than renal, deposition in the tissues or a shift of urate into the intracellular fluid. There is no evidence, as yet, for such effects. We have excluded the possibility of interference of the drug with the development of color in our method of urate analysis (see under Methods).

\section{Effect on glomerular filtration rate, electrolyte excretion and renal blood flow}

In eight of our thirteen patients given 1 to 2 $\mathrm{Gm}$. phenylbutazone intravenously there was no reduction in glomerular filtration rate as measured by inulin or endogenous creatinine clearance; the remaining five patients showed slight depression, most marked in the subject receiving the largest dose on the basis of body weight ( 35 mg. per Kg.). This is in agreement with the findings of Wilkinson and Brown (11), who noted no change in endogenous creatinine clearance, and Dupont, Duckert-Maulbetsch, and Fabre (12), who reported a mean depression in 24-hour endogenous creatinine clearance from 109 to 99 cc. per min. in eight subjects receiving intramuscular injections of $1 \mathrm{Gm}$. of phenylbutazone daily.

The retention of sodium and chloride uniformly noted in our experiments is in accord with the observations of previous investigators (10-14). That the decrease in excretion of these ions is primarily the result of increased tubular reabsorption is indicated by the significant reduction in $\mathrm{C}_{\mathrm{Na}} / \mathrm{C}_{\mathrm{In}}$ and $\mathrm{C}_{\mathrm{Cl}} / \mathrm{C}_{\mathrm{In}}$. A similar conclusion was reached by Dupont, Duckert-Maulbetsch, and Fabre (12) in their study on non-gouty subjects. The absence of any significant effect on potassium excretion agrees with the experience of others (10-14).

The rapid, marked and sustained depressions in $\mathrm{PAH}$ clearance noted by us are attributable to decreased renal tubular extraction of $\mathrm{PAH}$ rather than to reduction in renal blood flow, as indicated by marked decreases in $\mathrm{Tm}_{\mathbf{P A B}}$. Similar findings have been recorded by Berthoud (15) in connection with intravenously administered Irgapyrine. It is interesting to note that the effect of phenylbutazone in this respect is as marked as that of probenecid, whereas the associated uricosuric effects are much less pronounced. This dissociation would suggest that the mechanism of action of the two drugs on renal transport systems differs.

\section{SUMMARY AND CONCLUSIONS}

1. In ten gouty subjects receiving phenylbutazone intravenously in dosages ranging from 12 to $27 \mathrm{mg}$. per $\mathrm{Kg}$. body weight, $\mathrm{C}$ urate rose from a mean control value of $6.30 \mathrm{cc}$. per min. to a mean peak value of $19.3 \mathrm{cc}$. per min., and $\mathrm{C}$ urate/ $\mathrm{C}_{\text {In }} \times 100$ rose from a mean control of 6.04 to 19.5 within two hours. Elevation of $\mathrm{C}$ urate $/ \mathrm{C}_{\mathbf{C r}}$ continued for 20 to 22 hours. Uricosuria occurred in all ten subjects and the magnitude of this effect appeared to correlate with dosage.

2. In two patients receiving a slow intravenous infusion of phenylbutazone, elevations of $\mathrm{C}$ urate/ $\mathrm{C}_{\text {In }}$ were first noted at plasma phenylbutazone concentrations of approximately $10 \mathrm{mg}$. per cent. Stepwise elevation of $\mathrm{C}$ urate/ $\mathrm{C}_{\text {In }}$ occurred with rising drug concentrations in the plasma.

3. Eight gouty subjects were given phenylbutazone orally in dosages of $800 \mathrm{mg}$. per day. Seven showed increased urinary urate excretion 
but the duration and magnitude of this response was variable. All of the subjects exhibited a decrease in plasma urate concentration. In three an apparent inconsistency was observed between the degree of uricosuria and the decline in plasma urate concentration. Possible explanations are presented.

4. The glomerular filtration rate was unaffected in eight of thirteen gouty subjects following intravenous administration of phenylbutazone, the remainder exhibiting a slight depression in GFR. This effect continued for 20 to 22 hours in three of the subjects. The most profound depression in GFR, from 80.6 to $60.6 \mathrm{cc}$. per min. occurred in the subject receiving the largest dose, $35 \mathrm{mg}$. per $\mathrm{Kg}$. body weight.

5. A depression in $\mathrm{C}_{\mathbf{P A B}}$ from a mean control value of $495 \mathrm{cc}$. per min. to a mean minimum value of $326 \mathrm{cc}$. per min. occurred in ten subjects receiving phenylbutazone intravenously. This effect appeared rapidly and was sustained throughout the period of observation. In two subjects so studied the $\mathrm{Tm}_{\mathbf{P A B}}$ fell from control values of 75.4 and $61.4 \mathrm{mg}$. per min. to 12.9 and $14.0 \mathrm{mg}$. per min., respectively.

6. In three subjects intravenous phenylbutazone in doses of $800 \mathrm{mg}$. per day produced depressions of $\mathrm{C}_{\mathrm{Na}} / \mathrm{C}_{\mathrm{Cr}}$ and $\mathrm{C}_{\mathrm{Cl}} / \mathrm{C}_{\mathrm{Cr}}$ without appreciable changes in $\mathrm{C}_{K} / \mathrm{C}_{\mathrm{Cr}}$ and $\mathrm{C}_{\mathrm{P}} / \mathrm{C}_{\mathrm{Cr}}$. There was significant sodium and chloride retention.

7. The simultaneous administration of phenylbutazone and Benemid did not result in marked inhibition of the uricosuric effect of either drug.

8. The data indicate that the principal renal effects of phenylbutazone are upon tubular transport mechanisms, inhibiting the reabsorption of urate and the secretion of $\mathrm{PAH}$, and increasing the reabsorption of sodium and chloride.

9. Despite its uricosuric action, phenylbutazone is not recommended for protracted use as a uricosuric agent in chronic gout since its enhancement of urinary urate excretion is distinctly less than that of equivalent doses of probenecid and it is much more prone to produce serious toxic reactions.

\section{ACKNOWLEDGMENT}

The authors wish to express their indebtedness to Dr. J. J. Burns for many determinations of phenylbutazone concentration in plasma and urine; to Geigy Pharmaceuticals, Division of Geigy Co., Inc., for the generous supply of phenylbutazone used in these studies; to Miss Gertrude Chesin, Miss Anny Syarse, Miss Georgia Whitmore, and Mr. Edward Jaffe for their valuable technical assistance; and to Miss Marcia Kalin of the Dietary Service for her help in preparing the special diets.

\section{REFERENCES}

1. Kuzell, W. C., Schaffarzick, R. W., Brown, B., and Mankle, E. A. Phenylbutazone (butazolidin) in rheumatoid arthritis and gout. J. A. M. A., 1952, 149, 729.

2. Gutman, A. B., and Yü, T. F., Current principles of management in gout. Am. J. Med., 1952, 13, 744.

3. Sirota, J. H., and Yü, T. F., Effects of phenylbutazone (3,5-dioxo-1,2-diphenyl-4-n-butapyrazolidine) on urate clearance and other discrete renal functions in gout. J. Clin. Invest., 1953, 32, 605.

4. Sirota, J. H., Yü, T. F., and Gutman, A. B., Effect of Benemid (p-[di-n-propylsulfamyl]-benzoic acid) on urate clearance and other discrete renal functions in gouty subjects. J. Clin. Invest., 1952, 31, 692.

5. Goldring, W., and Chasis, H., Hypertension and $\mathrm{Hy}-$ pertensive Diseases, The Commonwealth Fund, New York, 1944.

6. Burns, J. J., Schulert, A., Chenkin, T., Goldman, A., and Brodie, B. B., The physiological disposition of phenylbutazone (Butazolidin), a new antirheumatic agent. J. Pharmacol. \& Exper. Therap., 1952, 106, 375.

7. Burns, J. J., Rose, R. K., Chenkin, T., Goldman, A., Schulert, A., and Brodie, B. B., Physiological disposition of phenylbutazone (Butazolidin), a new antirheumatic agent. Federation Proc., 1953, 12, 306.

8. Burns, J. J., Personal communication.

9. Kidd, E. G., Boyce, K. C., and Freyberg, R. H., Clinical studies of phenylbutazone (Butazolidin) and butapyrin (Irgapyrin) in rheumatoid arthritis, rheumatoid spondylitis and gout. Ann. Rheumat. Dis., 1953, 12, 20.

10. Chenkin, T., Brodie, B. B., Lee, P., Burns, J. J., Lowman, E. W., Goldman, A., and Steele, J. M., Physiological effects of phenylbutazone (Butazolidin) in man. Federation Proc., 1953, 12, 310.

11. Wilkinson E. L., and Brown, H., The effect of butazolidin (phenylbutazone) on water and electrolyte excretion. Am. J. M. Sc., 1953, 225, 153.

12. Dupont, P., Duckert-Maulbetsch, A., and Fabre, J., Modifications du métabolisme électrolytique et des fonctions glomérulaire et tubulaire sous l'influence des dérivés pyrazolés (Irgapyrine et Butazolidine). Helvet. med. acta, 1952, 19, 528.

13. Kersley, G. D., Watson, D., Brenner, J., and Millard, J. B., Butazolidine and salt excretion. Lancet, 1953, 1, 95.

14. Green, J., and Williams, P. O., Effect of butazolidine on the excretion of water and electrolytes. Lancet, 1953, 1, 575.

15. Berthoud, E., L'influence de l'Irgapyrine sur des fonctions rénales. Helvet. med. acta, 1952, 19, 428. 